\title{
LIX. Description of the Nymphæa Cærulea
}

\section{Julius Cæsar Savigny}

To cite this article: Julius Cæsar Savigny (1803) LIX. Description of the Nymphæa Cærulea, Philosophical Magazine Series 1, 15:60, 327-331, DOI: 10.1080/14786440308676283

To link to this article: http://dx.doi.org/10.1080/14786440308676283

$$
\text { 曲 Published online: } 18 \text { May } 2009 .
$$

Submit your article to this journal 준

III Article views: 2

Q View related articles $\asymp$ 
Dirfchaw, of very large dimenfions, and having the fame characters which diftinguith the one found on the Ohio.

Until the difcovery of this bone in America, the tradition of the Indians concerning the great buffalo has been confidered as entitled to very little attention. Many interpreted it as having entire reference to the mammoth, whofe preeminent fize was obvious, and whofe carnivorous teeth were well calculated to excite terror; but I have now no hefitation in believing that the tradition, which, with fuch little variation, prevails through all North America, mentioning the antient exiftence of a grcat buffalo, is a tradition really handed down to them from their forefathers, but, like all other traditions, clouded with fable: yet it is not improbable, fince we find the remains of the mammoth and the great buffalo in the fame country, that the diftinct ideas of each have been in time confounded, the terrible power of the one with the name of the other.

It has been too much the cuftom, whenever any large bones have been found in Europe, to call them all elephants' bones; and in America, to think them all belonging to the mammoth: but from the progrefs now made in this inquiry there is reafon to hope for additional light on this interefting fubject, whether it be confidered as a foundation to theological faith, or regarded as a confpicuous monument in the hiltory of the world.

LIX. Defription of the Nymphæa Cærulea. By JuLIus CASAR SAVIGNY, of the Injtitute of Egypt*.

I $I_{T}$ is well known that the lotus of the antient Egyptians was one of the moft celebrated plants of antiquity. Rifing every year with the waters of a river which overflowed its banks only to fecundate the earth; fpringing up amidlt plains formerly defert, which it embellifhed with its beautiful flowers; and cultivated to ferve as food to the leaft fenfual, but the moft numerous clafs of the inhabitants; it was judged worthy of bomage by one of the firft people in the world, who confidered it as the happy fign of abundance, and as a facred pledge of the favour of the gods.

It is to the genus of the nymplaca that the modern botanitts have referred the lotus, which has been defcribed by molt of the antient hiftorians, and which is engraven on all the antique momuments of Egypt. Two fpecies of this grenus,

$$
\text { * From Amales dut Mufeum National, No. } 5 .
$$


one with white and the other with azure flowers, fill ornament, during the time of the inumation, the furface of the canals and rivers, and in general of all the fields cf Lower Egypt, which are covered by the waters of the river. Plants fo fimilar were no doubt butidu by the Egytians with equal veneration; and though Linnaus, who was well acquainted with the former, gave it the name of lotus, it is to be prefumed that the fecond procured the fame advantages and ferved for the fame myfteries. Its flowers bave more fplendour and a fwceter fmell, and the azure colour they exhibited might become, among a people fo religious, the emblem of the refidence of the deity on the waters.

The nympeca lotus is very well defrribed, and a good figure is given of it, in feveral Syftems of Butany; but the cdite is not the fame with thofe the flowcrs of which are azure-coloured. It was furcely obferved by a few travellers, and if mentioned, it was only in a vague and incored maner. Forkal, who travelied through foypt in $i g$ ris, atd $a$ bo gave a Flora of that country, did wot observe t. Fin flence in this refpeet is the more afionithing, as the plint in quefion

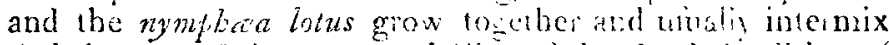
their leaves. It is not enten indicated it ihe latt edition of the Syjema Nature, pullifhed by Grecin. This aubor, bon ever, colleged with grat attention all the tatcond fpecies to be found in the difforent works which lats bitherto appeared *

It is therefore indifpenfably necefary that a name and fpecific character flonld be affignd to this nymplyat it is

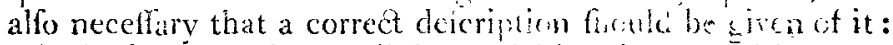
this, in fome meafure, will be enrohing lonary wib a new plant; and this, incled, is the objat which l propofe in the prefent memoir.

But as this fpecies has a great refemiance to the $n$ mploca lotus, and as it is poffible that they may have ofien been confounded. I have thought it will be of advantage to give a comparative defcription of both. By the fe neans the reader will be better euabled to comprehend the characters by which they are diftirguibed, and which render it necefiary to form of them two feparate fpecies.

The root of the nymplea lotus, and that of the other fpecies, which from the colour of its fowers 1 have called the azure nenuphar (nynpleca carulea), confifit of long, white, pulpy flaments, the upper extremities of which acthere to round tubercles. In feveral provinces of Egypt thefe tuber-

* Wildenow in his species Planiarum does not fpeak of this nympinea.

cles, 
cles, and prticliarly thofe of the firif fpecies, are plucked up afee the intundation: thev are ufed as food; they have an infipat earthy tafte, and orm a delicaic with.

the tetves of both ::e large, pretty numerous, fub-orbicul ir, divided ino two lobes from their bafe to the place where the petiole is inferted that is to fay, nearly to the niddle of tre cifk. They are not fo thick as thofe of our numuphas in Eurnpe: they have a darker green colour, and a thrning appearance above; and below are often tinged with furite or violet. Thefe leaves are fupported by radical cylinute putinles, flightly compreffed and fometimes very long, which 3 at on the furface of the water.

the Hixwcr are very large, and are often more than four inches in thineter. Their pedicles, which arife from the rum, aw inin :rous ard differ very little from the petioles.

The colit of thefe fowers is crinyoled of eight leaves difp.r. in war r.ws, and coloured in the infide: the more in terin sues a the molt coloured, and have fome refemblance to the netioles.

The latter, from twelve to twenty in number, are alfo difpofed in feveral feries.

The ftamina are of a yellow colour with large filaments, and petaliform.

The ridii of the ftigma vary, for the moft part, in number from twelve to iwenty-five. They have the fame colour as the ftanisa, are compreffed and flightly bent at the fummit.

Such is the common appearance of the roots, the leaves, and the flowers. Let us now examine the differences they exhibit.

The leaves of the nymphea lotus are bordered quite round with very acute indentations, firm and almoft like prickles: their lobes. for the muft par!, are exactly parallel and fometimes even; they converge, and nutually cover each other: their inferior furiace is charged with very prominent ribs, which furm a very apparent reticulation: their petioles are rough.

On the other hand, thole of the nympbea carulea have their edges farcely finuated; their lobes are more pointed, and commonly divergent. The inferior furface exhibits ribs f'arcely fenfible, the principal ones of which only are fomewhat prominent; the reft being concave and lefs elevated thin the difk. The petioles of thefe leaves are exceedingly rough.

$n$ the nympraca lotus the leaves are always more open. The folioles of the calyx are oval, lanceolated, greenith exter- 
nally, without fpots, but marked with feven paler ribs very diftinct.

The folioles of the calyx in the nympbea corulea are much narrower, lanceolated, and almoft cunciform : the extcrior fide of them is of a dark green colour, conftantly varied with an infinite number of points and finall lines of a purplith colour, and have no apparent ribs.

The petals of the nympbea lotus are oval, lanceolated, and very unequal; thofe of the laft being much fmaller than the reft : their colour is a pure milk-white, tinged with a greenifh purple colour on the outfide, but rarely,

In the nympbea carulea the petals are lanceolated all perfectly equal, of a bright white colour, tinged, in particular towards the fummit, with the moft beautiful azure, inclining Nightly however, fometimes, to violet.

The ftamina of the nymphea lotus have anthers very much comprefled, lanceolated, without any appendix at the fiummit, and have fcarcely the length of the filaments.

On the other hand, the antheræ of the nympiaca carulea are very little compreffed, lineal and longer than the filaments ; their fummit is terminated by a fubulated blueith appendix fimilar to a fmall petal.

In the laft place, the fummits of the radii of the ftigma are longer and fubulated in the nympbea lotus; fhorter, oval, and lanceolated, in the nympba a carulea.

The fmell exhaled from the flowers of each kind is alfo very different: that of the nympbea carulea is exceedingly fweet and agreeable; that of the nympbac lotus is ftronger, more pungent, and much lefs agreeable.

In regard to the fruit, I did not find in them any very remarkable difference: in both fpecies it confitts of a dry round berry, which is long, covered by the bafes of the folioles of the calyx and thofe of the petals; truncated and radiated at the funmit, which is always ftained by the decompofition of the flamina and interior petals : it is divided into feveral cells, each of which correfponds to a raclius of the ftigma, and contains a quantity of round feeds of a rofe colour.

The Arabs have very well diftinguifhed thefe plants, and given to each a particular name: the former they call neoufar, and the latter bacbenin.

By felecting from the defcription here given the moft prominent differences, both fpecies may be characterized as follows:

Nymphes Lotus,

N. foliis dentatis, antberis apice fimplicibus.

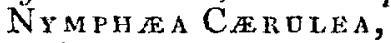

N. folits repundis, antberis apice fubulato-petaloïdeis. 
x. A petal.

Explanation of tbe Plati. (VII.)

2. A ftamen of the interior feries.

3. A ftamen of the exterior feries.

4. The ovarium and ftigma.

5. The feeds.

6. A fection of the pedicle.

LX. On Mr. Greathead's Life-Boat*. SI R,

A considerable time has elapfed fince I had the honour $t o$ lay before the Society a model of the bife-boat of my invention.

I have now enclofed a particular account of its conftruction in a letter finm Mr. Hinderwell, explaining upon what principle it is built, fo as to render it fuperior to any other form of a boat for the dangerous enterprifes for which it was intended, and has been ufed.

$$
\begin{aligned}
& \text { I am, Sir, your humble fervant, } \\
& \text { Henry Greathead. }
\end{aligned}
$$

South Shi-lds,

Jan. $x,: 8 \sim 2$.

To Mr. Cbarles Taylor.

SIR,

IT is much to be lamented, that in an age enlightened by feicuce, fuch a languid indifference thould prevail on many important public occafions; and that the moft excellent inventions fhould have to combat the force of inveterate prejudice.

How many valuable difcoveries have languifhed in obfurity! How many ufeful projects have perifhed in embryo, deprived of the foitering aid of the public, and the patronage of influence and authority! In the clafs of ufeful improvements for the diminuion of the dangers incident to a maritime profeffion, the life boat, invented by $\mathrm{Mr}$. Greathead, of Shields, has a claim to a diftinguifhed patronage. An experimental conviction of its great utility in faving the lives of hipwrecked feamen, and of its perfect fafety in the moft agitated fea, has induced me to advocate the caufe with a

* From the Tranfaclions of the Society for the Excouragement of Arts, 8.c. fur 1302 . The Society's gold medal and fifty guineas were voted to Mr. Greathead for this invention. 